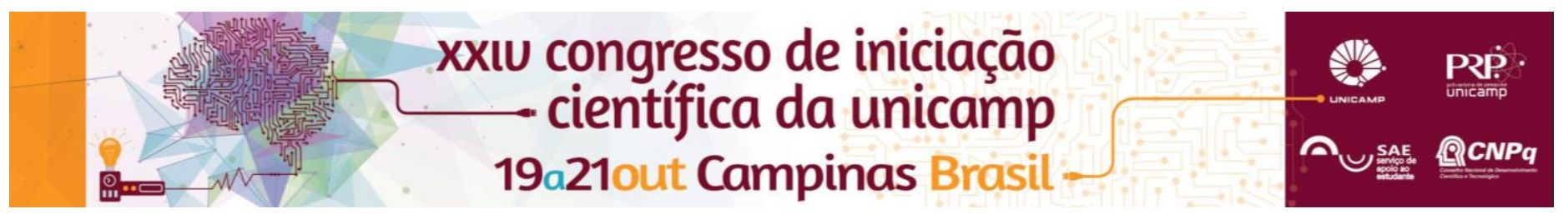

\title{
REPENSAR ‘COMUNICAÇÃO’ À LUZ DA TECNOLOGIA E DA INTELIGÊNCIA ARTIFICIAL
}

\author{
Guilherme C. Silva*, Tales Tomaz
}

\begin{abstract}
Resumo
Os estudos em comunicação usualmente têm tomado como base a noção de que a comunicação ocorre em um esquema técnico no estilo 'emissor-receptor'. Nesse paradigma, um meio de comunicação é algo 'neutro', através do qual alguém se comunica com outro ser humano. Essa visão, no entanto, encontra desafios atualmente com o avanços tecnológicos e da inteligência artificial, que parecem não se deixar definir como meros 'meios'. O trabalho discute essas questões e seu impacto para a noção de comunicação.
\end{abstract}

\section{Palavras-chave}

Comunicação, Inteligência Artificial, Tecnologia

\section{Introdução}

A pergunta sobre 0 sentido da comunicação foi problematizada desde o início do século $X X$. Até aqui, o paradigma predominante para a compreensão da comunicação veio através das análises cibernéticas dos matemáticos Claude Shannon e Warren Weaver ${ }^{1}$, nos anos 40, que elaboraram um esquema técnico onde a comunicação é um processo diádico delimitado, por um lado, por uma fonte de informação, e, por outro lado, por um receptor. Mesmo desenvolvimentos posteriores, como o de Horkheimer e dos Estudos Culturais, apenas complexificaram e adicionaram outros elementos a este modelo técnico.

Tendo em vista os recentes avanços na compreensão da tecnologia e, especialmente, da inteligência artificial e as possibilidades em vista da criação de um 'outro' artificial, o trabalho busca questionar: "Como a noção contemporânea de tecnologia, especialmente com os desdobramentos mais recentes, contribui para repensar a noção de comunicação? O paradigma técnico, dominante na comunicação e com uma visão utilitarista dos meios, responde efetivamente aos novos desafios?

\section{Resultados e Discussão}

No paradigma técnico da comunicação, é comum se considerar meios de comunicação, como rádio, jornal, televisão, computador e, agora, a internet - como sendo 'neutros', meios para um fim. A postura do homem é mais ou menos a definida por Sfez (1994, p. 14)2: "Sou um ser vivo que se serve da máquina, que 'faz com'. Situo-me como um ser completo, acompanhado de alguns instrumentos úteis, mas que permanecem exteriores à minha definição". Porém, essa ideia tem sofrido persistentes críticas no meio acadêmico. Martin Heidegger (2000, p. 9) ${ }^{3}$, por exemplo, colocou que a "essência da técnica não é, de modo algum, algo técnico". Assim como na conhecida lenda dos índios de Taos, no Novo México, para ele, um 'meio' é, em essência, um modo de compreensão do que é real naquilo que ele mostra como real. Além disso, o paradigma técnico, de Shannon e Weaver, é reconhecidamente fruto da cibernética, a ciência do 'controle, de Wiener. Uma das premissas básicas da cibernética é de que "o mundo pode ser reduzido à informação digital, abordado como um sistema padronizado de informações numéricas que pode ser processado e, assim, conservado e manipulado de forma ilimitada" (RÜDIGER, 2008, p. 176). Tal visão, somada ao avanço de sofisticação dos instrumentos técnicos, lança uma intrigante questão: Afinal, se não há diferença 'essencial' entre o ser humano e um aparato técnico e, este, por exemplo, puder não apenas simular, mas, de fato, participar de forma ativa e criativa de uma interação com o homem, pode-se dizer que há comunicação aí? Pode-se afirmar, pelo paradigma técnico, que tal aparato é apenas um meio de transmissão?

Comunicólogos, sociólogos, filósofos e teóricos de outras vertentes têm se debruçado sobre o tema e descoberto uma nova possibilidade para os estudos em epistemologia da comunicação.

\section{Conclusões}

É possível perceber que o paradigma técnico dominante na compreensão de comunicação necessita de uma revisão ou, até mesmo, de substituição. A tecnologia, especialmente pelo que foi evidenciado com a inteligência artificial, obriga a questionar o próprio significado da palavra comunicação e do seu esquema original. A explicação técnica de Shannon e Weaver é refém de uma concepção instrumental da técnica, que pressupõe que o meio é um instrumento que está nas mãos do ser humano. Entretanto, Heidegger mostrou como é limitada essa compreensão da tecnologia, afinal, esta é muito mais uma forma específica pela qual o real se apresenta. Como se isso não bastasse, os avanços da inteligência artificial estão levantando a questão sobre quem ou o que é o outro - aquilo com o que se comunica. A conclusão é de que, definitivamente, deve-se repensar o que é comunicação, como já aludiu Marcondes Filho (2009).

\section{Agradecimentos}

Ao apoio do Grupo de Estudos em Cibercultura e Comunicação (Geccom), do Centro Universitário Adventista de São Paulo (Unasp)

\footnotetext{
${ }^{1}$ WEAVER, W. A Teoria Matemática da Comunicação. In: COHN, G. (Org) Comunicação e Indústria Cultural. São Paulo: Nacional, 1977.

2 SFEZ, L. Crítica da Comunicação. São Paulo: Edições Loyola, 1994.

${ }^{3}$ HEIDEGGER, M. Vorträge und Aufsätze. Frankfurt: Vittorio Klostermann, 2000 .

${ }^{4}$ RÜDIGER, F. Cibercultura e pós-humanismo: exercícios de arqueologia e criticismo. Porto Alegre: EDIPUCRS, 2008
} 